\title{
Diagenesis of Holocene reef and associated beachrock of certain coral islands, Gulf of Mannar, India: Implication on climate and sea level
}

\author{
S Krishna Kumar ${ }^{1,3, *}$, N Chandrasekar ${ }^{1}$, P Seralathan ${ }^{2}$ \\ and J DAJKUMAR SAHAYAM ${ }^{1}$ \\ ${ }^{1}$ Centre for Geotechnology, Manonmaniam Sundaranar University, Tirunelveli 627 012, Tamil Nadu, India. \\ ${ }^{2}$ Department of Marine Geology and Geophysics, Cochin University of Science and Technology, \\ Cochin 682 016, Kerala, India. \\ ${ }^{3}$ Present address: Department of Civil Engineering, St. Peters University, Avadi, Chennai 627 054, India. \\ ${ }^{*}$ Corresponding author.e-mail: coralkrishna@yahoo.co.in
}

The reef and associated beachrock from certain Gulf of Mannar islands (Rameswaram, Kurusadai, Shingle and Appa Island) were studied to assess the diagenetic evidences. Sixty samples were collected from marine terraces and reef platforms. The samples comprised of coral rubbles, shell fragments and lithic fractions. The presence of corals in the form of framework or isolated patches on the reef flat suggests the rapid increase of accommodation and probably absence of terrigenous and siliciclastic inputs. Moreover, the massive coral heads above the transgressive phase suggest the maximum flooding and relatively deepest facies. The freshwater dissolution, association of marine and meteoric cements suggest the semiarid climatic condition with marine diagenesis during sea level lowstands and recharge of freshwater lenses during periodic rainfalls. In addition, the interaction of these mixed carbonate, siliciclastic sediments results in silicification of carbonate components. The reef associated beachrock were deposited in low energy environment with some amount of terrigenous matters derived from Precambrian basement rocks and transported into reef area by ephemeral streams and longshore sediment transport. The incorporation of coral fragments within the siliciclastic sediments are most probably due to the erosion and re-deposition of the sediments.

\section{Introduction}

Paleoclimate reconstruction in the tropics has emerged as an important tool for exploring the natural bounds of climate variability. Long lived, massive corals provide valuable natural archives of tropical climate and fossil corals provide 'windows' into climates of the past (Helen Mcgregor and Gagan 2003). The diagenesis effects on carbonate sediments are possible to affect the coral proxy records including sea level and climatic variations.
The process of diagenesis in corals refers to the precipitation of secondary aragonite or calcite in skeletal voids, or the replacement of skeletal aragonite, usually with calcite (Bathurst 1975). During this transformation, the composition of corals and trace elements are exchanged and removed from the coral matrix. An increasing number of climate records are being produced from subaerially exposed corals of Holocene and Last Interglacial age, which may be subjected to diagenesis, primarily in the vadose zone (Woodroffe and Gagan

Keywords. Coral reefs; beachrock; diagenesis; Gulf of Mannar. 
2000). If diagenesis occurs in the vadose and subtidal zone, corals are most likely to transform to calcite and secondary aragonite respectively. Several comprehensive studies were carried out on the diagenesis of carbonate sediments worldwide (Andre Strasser and Strohmenger 1997; Muller et al 2001; Perrin 2003; Nicola Allison et al 2007; Hussein Sayani et al 2011). In India, the carbonate composition and diagenetic variables from west and east coasts of India have been documented by various researchers (Rajamanickam and Loveson 1990; Ramkumar et al 2000; Purnachandra Rao et al 2003; Ramkumar 2008). However, very few investigations on diagenesis have been carried out in this study area. Under these circumstances the aim of the study is to describe the diagenetic history of Holocene reef and associated beachrock deposits, Gulf of Mannar, Tamil Nadu, India.

\section{Study area}

Gulf of Mannar coastal stretch extends from Tuticorin to Rameswaram Island in the SW-NE direction to a length of about $140 \mathrm{~km}$. The beaches of the study area are chiefly composed of lithic fractions, shell fragments, shrub vegetations and coral rubbles. The island of Gulf of Mannar developed at an average of about $8-10 \mathrm{~km}$ from the coast. These islands are broadly classified into different groups (Tuticorin, Vembar, Keelakkarai and Rameswaram) with respect to the distance from the mainland. The temperature varies from $22^{\circ}$ to $37.5^{\circ} \mathrm{C}$. The annual rainfall in the study area is $900 \mathrm{~mm}$. The maximum area extension of Gulf of Mannar coral reef is about $61.01 \mathrm{~km}^{2}$. The radio carbon ages of Rameswaram and Keelakkarai terraces are $5440 \pm 60,4020 \pm 160$ and $3920 \pm$ 160 years BP (Stoddart and Gopinathapillai 1972; Rajamanickam and Loveson 1990). The age of the terraces suggests that they are formed during the marine transgression mid-Holocene period.

\section{Methodology}

The extensive fieldwork was carried out in certain coral islands of Gulf of Mannar (Rameswaram, Kurusadai, Shingle and Appa Island, figure 1). The samples were collected with special consideration from beachrock terraces, massive coral rubbles and stratigraphic relationship of the strata. Totally 60 samples were collected to assess the diagenetic history of the coral islands. Thin sections were made from all the samples. Twenty eight samples were slightly etched with dilute $\mathrm{HCl}$ and mounted in the SEM stub before the thin layer of silver paint was coated at the bottom of the sample for better conduction. The sample was coated with gold palladium alloy in a vacuum chamber to maximize the signal and improve spatial resolution. Bulk Xray analysis was performed on all samples (modelBruker AXS D8 advance). The mineralogy of the cements was determined from the crystal morphology and was conformed by energy dispersive spectrometer (EDS) during SEM analysis. The SEM and EDS were performed using JEOL JSM 6360 and JEOL JED 2300 models at the University of Madras, Chennai and Cochin University of Science and Technology, Kochi.

\section{Facies sequences}

In the study area, three well developed major carbonate facies are classified based on their lithology. The changes in sedimentation pattern are creating small scale facies due to minor sea level fluctuation and climatic changes (figure $2 \mathrm{a}, \mathrm{b}$ and $\mathrm{c}$ ). The older facies has been made up of lithified beachrock formations. The middle facies consists of constructed reef (globular and branch corals) and faunas with lithic fragments. The younger facies is purely made up of lithic fragments and it overlies in the middle facies. The erosion features and cliff formation between the older and younger reefs suggest the sea level fluctuations (figure 3a, b). Living corals subsist locally in shallow depressions. During the period of low tide, spring reef flat is covered by water. With subsequent sea level rise many portions of the older reefs were exposed in sea water for certain period before it has been covered by sediment deposits. They are perforated by boring organisms and encrusted by red algae. In order to form these reef sequences, accommodation had been created due to sea level variations. The presence of corals in the form of framework or isolated patches on the reef flat suggests rapid increase of accommodation, absence of terrigenous and siliciclastic inputs.

Moreover, the massive coral heads above the transgressive phase suggest maximum flooding or relatively deepest facies (figure $3 \mathrm{c}, \mathrm{d}$ ). This is also supported by red algae distribution. The coral rubbles or reworked siliciclastic matters are found as small patches in the facies sequences, which indicate the early transgressive phase and is stabilized by mangrove plants. The incorporation of coral fragments within the siliciclastic sediments are most probably due to the erosion and redeposition of the sediments (figure 3e). Several transects of beachrock is extended towards the 


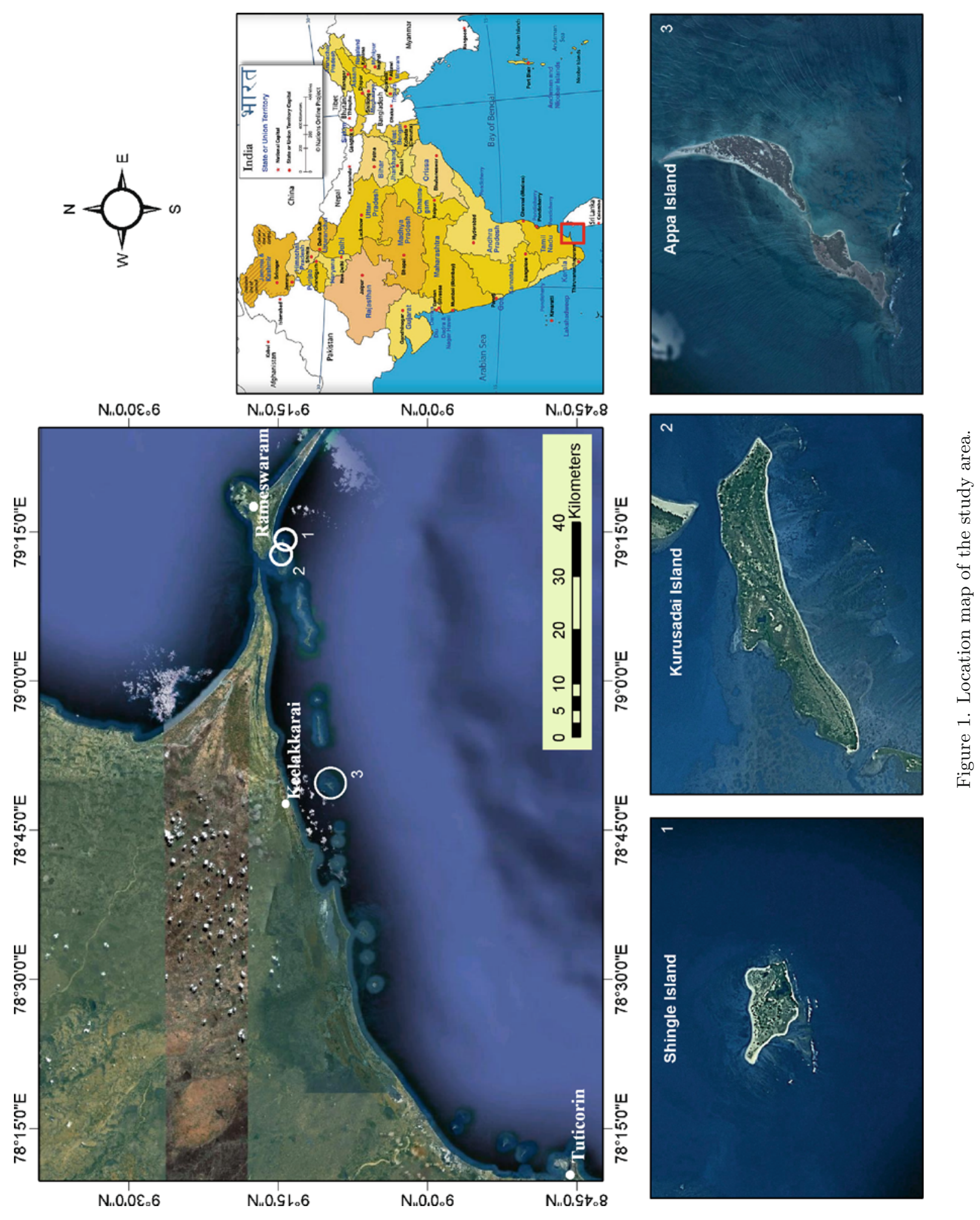



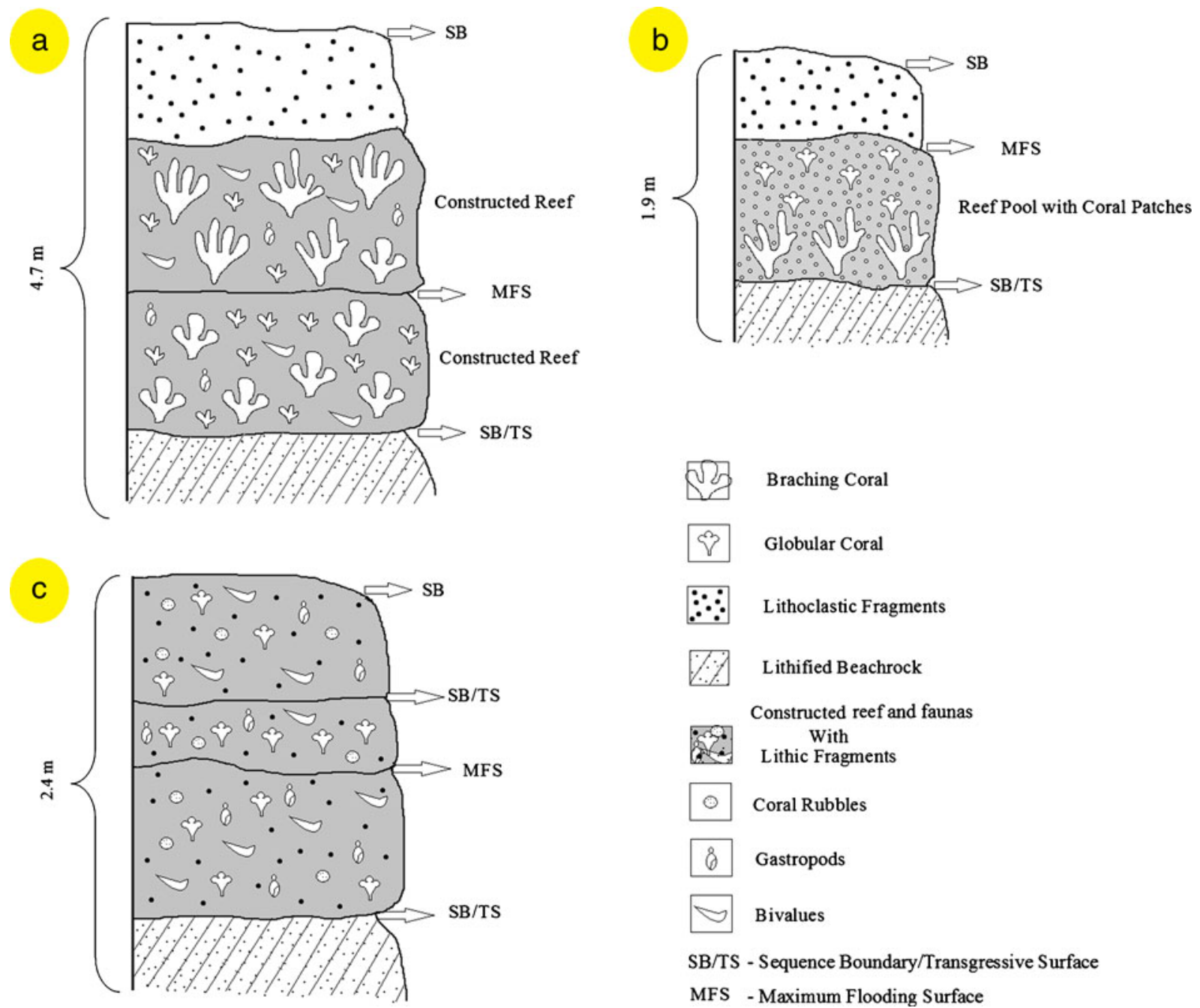

Figure 2. (a, b, c) Different types of small scale facies encountered in the study area.

seawardside by wave reworked coral rubbles (figure 3f). The arrival of siliciclastic sediments reduced the carbonate phase in the reef flat. The deposited sand shows the beach laminations and evidences of beach materials. The well sorted and mediumto-fine grained nature of the sediments represent marine environmental deposition. A detailed petrographic study of various lithologic types has been documented based on carbonate rock classification of Dunham (1962). The changes of facies and microfacies within short distance show the rapidly changing depositional environment of the reef complex.

- Reefal framework is stabilized by encrusting foraminifera, bryozoans, crusts of red algae and microbial coatings (figure 4a). The intra-skeletal porosity is filled by fine grained bioclastic fragments, arenite, wackestone and packstones or is free from sediments. Voids in the reef framework are filled by fine grained micrites or sparites. This is implying locally by varying energy conditions (figure 4b).

- The bioclastic wackestone, packstone with bivalves, gastropods, foraminifera, ostracoda, red algae and lithoclasts reflecting the sedimentation under quit environment (figure 4c). However, the presence of Acropora species in the periphery of study area is supported further towards a low energy environment.

- The bioclastic grainstone were deposited in the reef environment especially in reef pools by wave and storm action. The siliciclastic dominated facies chiefly consists of subangular to subrounded quartz, feldspar grains and fraction of carbonate particles. The siliciclastic dominated facies formed the beachrock by lithification process (figure $4 \mathrm{~d}$ ). 

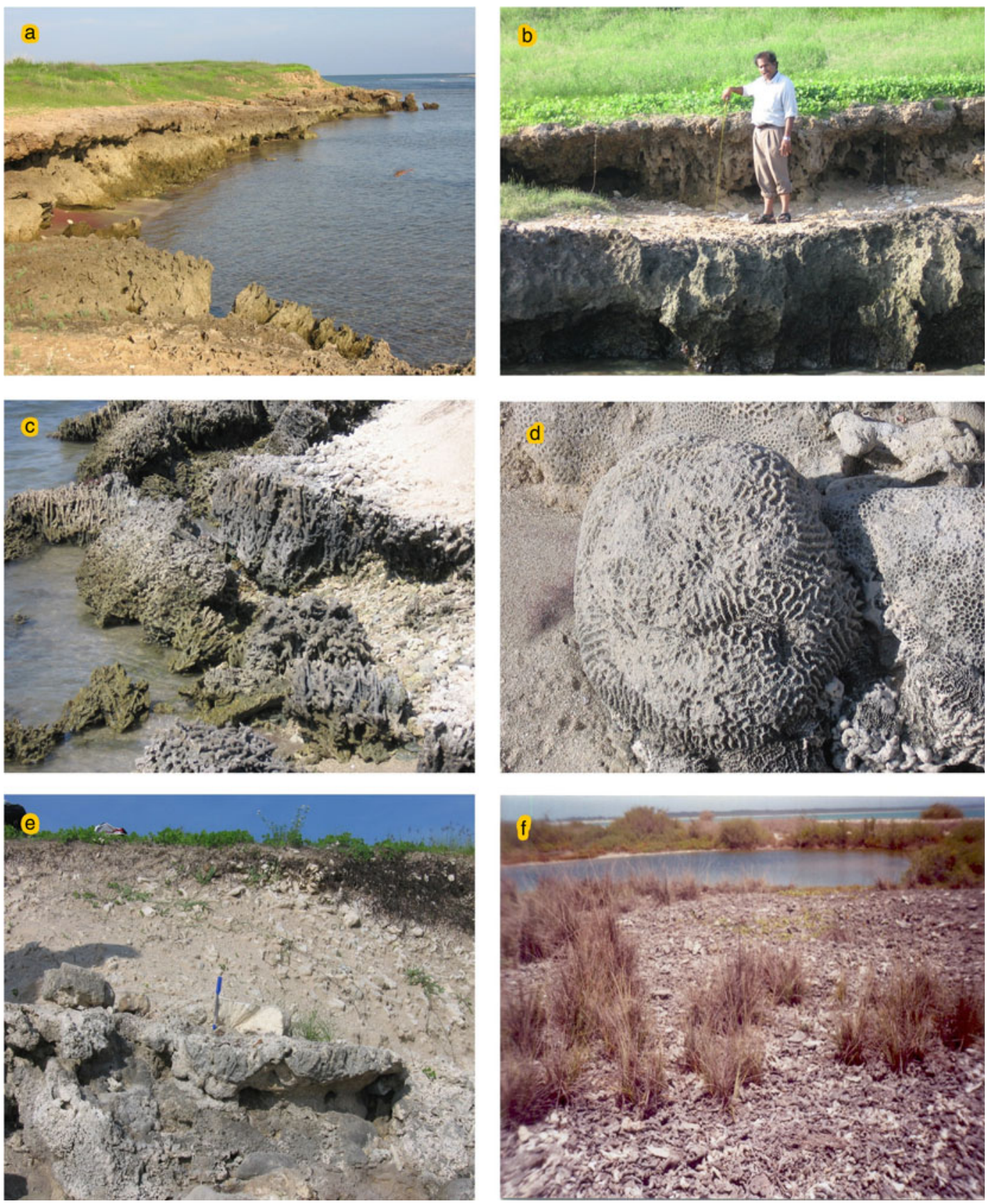

Figure 3. Outcrop photographs. (a, b) View of well developed reef terraces and cliff formations of the coral Island (the upper and lower terraces about 0.8 and $1.6 \mathrm{~m}$ respectively). The upper part of the terraces chiefly covered by aeolian sand dunes and it is stabilized by small grass like plants. (c, d) The massive coral heads and branch coral colonies in the seaward side of the reef facies. The framework deposits of the coral are covered by sand dunes. (e) Fine grained aeolian facies associated with coral rubbles, which are overlain above the coral massive. (f) Coral rubbles are deposited in the seaward side of the Shingle Island due to wave, storm and current reworking of reef debris.

\section{Diagenetic features}

\subsection{Reef associated beachrock}

The beachrock chiefly consists of bioclastic framework of coral rubbles, foraminifers, other shell fractions, algae and lithic fractions. The clastics chiefly consists of quartz, feldspar and opaque minerals. The size of the grains is from mediumto-fine grain with subangular-to-subrounded in nature. The other skeletal fractions include brachiopods, gastropods, mollusks, bryozoans, etc. The foraminifers are dominantly represented by Nummulites, Quinqueloculina and Ammonia beccarrii (Krishna Kumar et al 2011). The biological assemblages in the exposed beachrock and terrace clearly indicate the intertidal environmental condition. Acropora, Porites and associates like Diploastrea, Cycloseris and Goniapora are common (Banerjee 2000). Precipitation of carbonate 

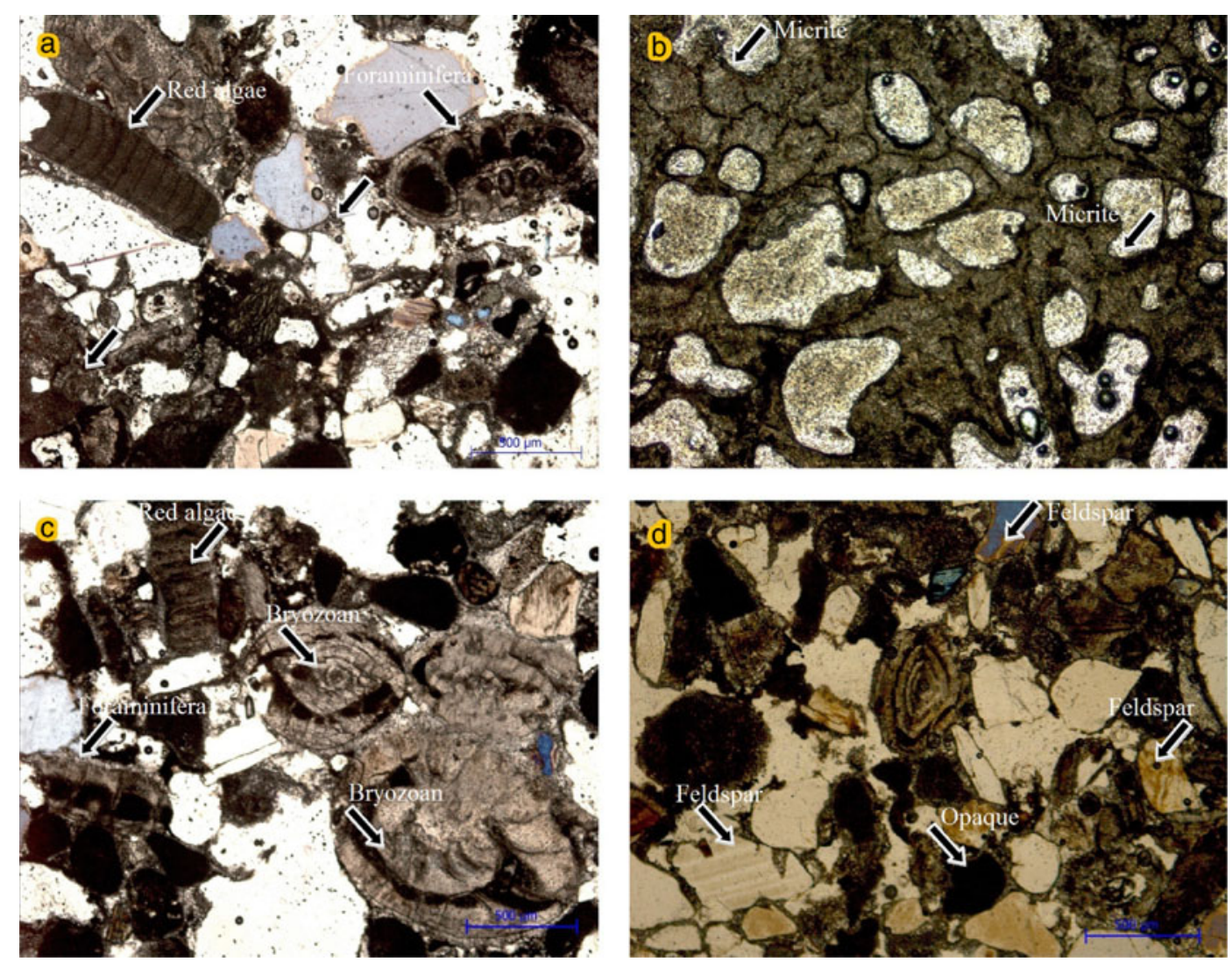

Figure 4. Typical photomicrograph of the microfacies. (a) Crusts of foraminifera, bryozoans, red algae and microbial coatings were stabilized the coral framework. The remaining pore spaces and sand grain boundaries are filled by micritic sediments or by peloidal cements. (b) Voids of the constructed reef facies are filled by fine grained micrites or sparites. (c) The bivalves, gastropods, foraminifera, ostracoda, red algae and lithoclasts are associated with the bioclastic wackestones/packstone, which is reflecting the sedimentation relatively under quit environment. (d) Coarse grained bioclastic facies consist of fragmented bivalves, gastropods, benthic foraminifera and red algae. This facies are associated with moderate to well rounded lithic fragments, especially quartz and feldspar grains and the early cementation in this facies are made by $\mathrm{Mg}$ calcite.

cement in beachrock sediments may be inorganic or biologically mediated (Gischler and Lomando 1997). The coral and foraminiferal tests are filled with micritic cements. The poorly preserved micrites in few samples were enveloped in secondary porosity voids probably by partial leaching. The formation of micritic crystals within the skeletal voids depends on the diagenetic intensity, local hydrology of the area and circulation of the diagenetic fluids. It significantly indicates the subtidal environmental conditions. The micritic envelopes were developed below the inner part of the reefassociated deposits of islands due to inundated water. The well preserved foraminiferal tests in few beachrock samples are probably due to weak diagenetic process.

\subsection{Younger reef}

Diagenesis in the younger reef complex is dominated by the precipitation of aragonite, high $\mathrm{Mg}$ calcite and micritic cements. The low $\mathrm{Mg}$ calcite cement also occurs in the beach and aeolian sand covered younger reefs. The aragonite cement occurs mostly in reef facies like pool corals and coral rubbles. The progressive precipitations of marine inorganic aragonite cements in corals indicate the early stage of diagenesis. High Mg calcite cements are occurring in reefal, peri-reefal and beachrock facies. The high $\mathrm{Mg}$ calcite cements are commonly associated with aragonitic cements. The micritic cements cover particles and the earlier cements display crystal shapes of typical low Mg calcite.

\section{Diagenetic settings and marine diagenesis}

The framework reef and associated beachrock around the island provides remarkably favourable environment for the precipitation of marine cement (figure 5a). However, marine cementation and other diagenetic process are limited in the 

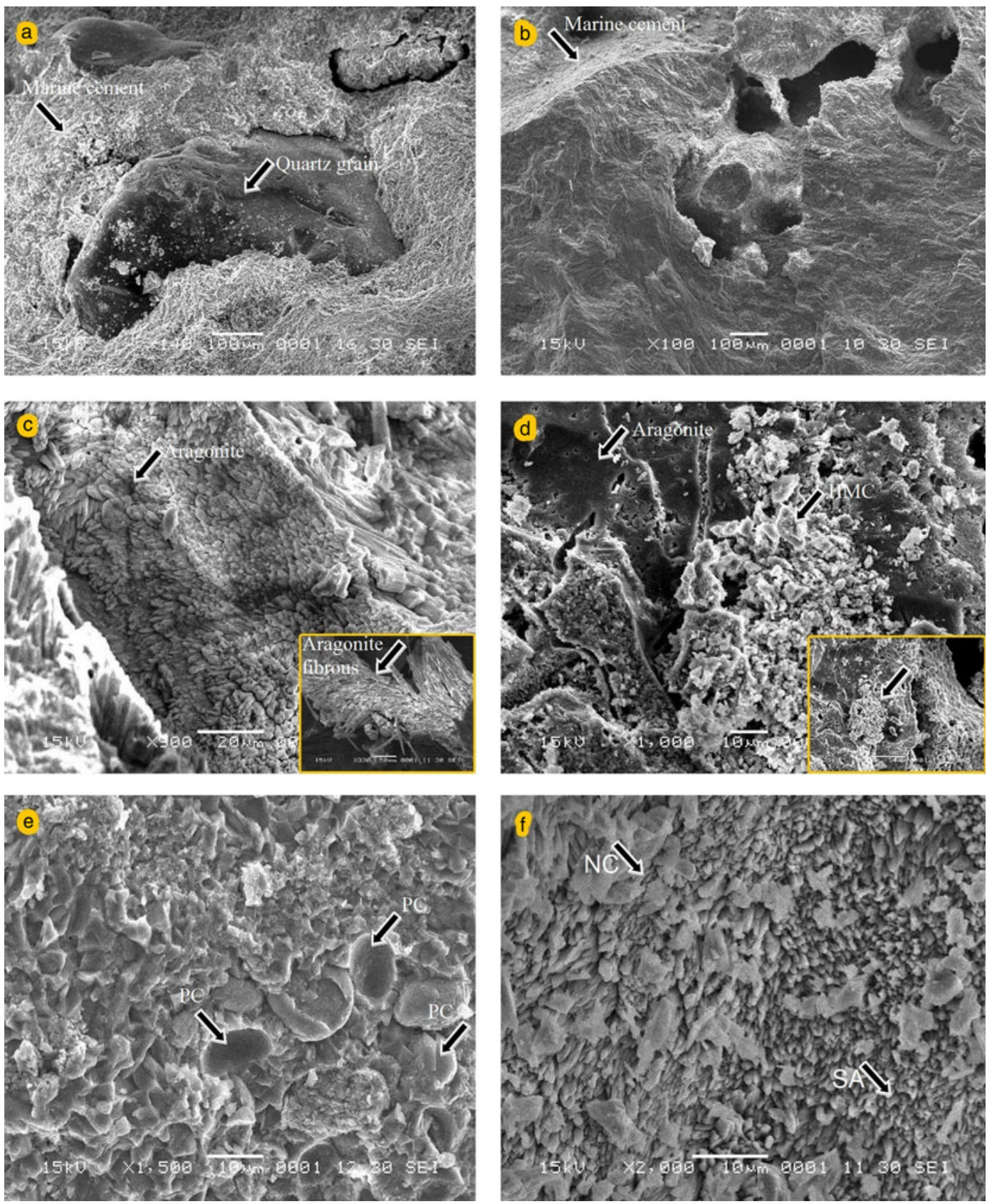

Figure 5. Diagenetic features of the coral reef deposits. (a) The framework deposits showing precipitated marine cement with sub-angular quartz grain. (b) The reef flat showing the precipitated massive marine cementation in the reef frame is due to the supply of fresh marine water. (c) Aragonite fibrous, needle shaped crystals (inner figure showing fibrous aragonite crystals) are growing from same coral deposit which reveals the younger generation cements. (d) The association of aragonite and high $\mathrm{Mg}$ calcite (HMC) growing in the same sample showing the influence of substrate in the cementation process (inner figure shows presence high $\mathrm{Mg}$ calcite around the fissures). (e) The development of peloidal cement (PC) in the reef deposits is an indication of the microbial activity. (f) The development of low Mg calcite (Neomorphic calciteNC) above the aragonite cements (Secondary aragonite-SA) in the reef deposits indicates the two-generation cements. The occurrence of two types of cements is due to the supply of meteoric water into the reef framework after the formation of marine cementation.

beachrock due to hard and little porosity impact. Reefs are situated along shelf margin in the areas of high wave. The tidal activity supplies the unlimited volumes of fresh and cool marine water. This water is rapidly degassed relative to $\mathrm{CO}_{2}$ by agitation, warming and organic activity leading to further saturation with respect to $\mathrm{CaCO}_{3}$ and ultimately to massive cementation within reef frame (figure 5b). This process is well documented by various researchers in the modern reef around the 
world (Land and Moore 1980; Andre Strasser and Strohmenger 1997).

Fibrous needle shaped crystals with pointed or blunt end aragonite crystals commonly occur on substrates (figure 5c). Aragonite and high $\mathrm{Mg}$ calcite cements typically precipitate in active marine phreatic diagenetic environments (Longman 1980). The association of aragonite and high $\mathrm{Mg}$ calcite found in same samples suggested that the substrate played an important role in their nucleation (figure 5d). The high $\mathrm{Mg}$ calcite crystals tend to grow peloidal cements, which indicate the favourable condition for microbial activity (figure 5e). The aragonite and high $\mathrm{Mg}$ calcite crystals develop on micritic lining and on microbial films. Marine cements are abundant in the boundaries of
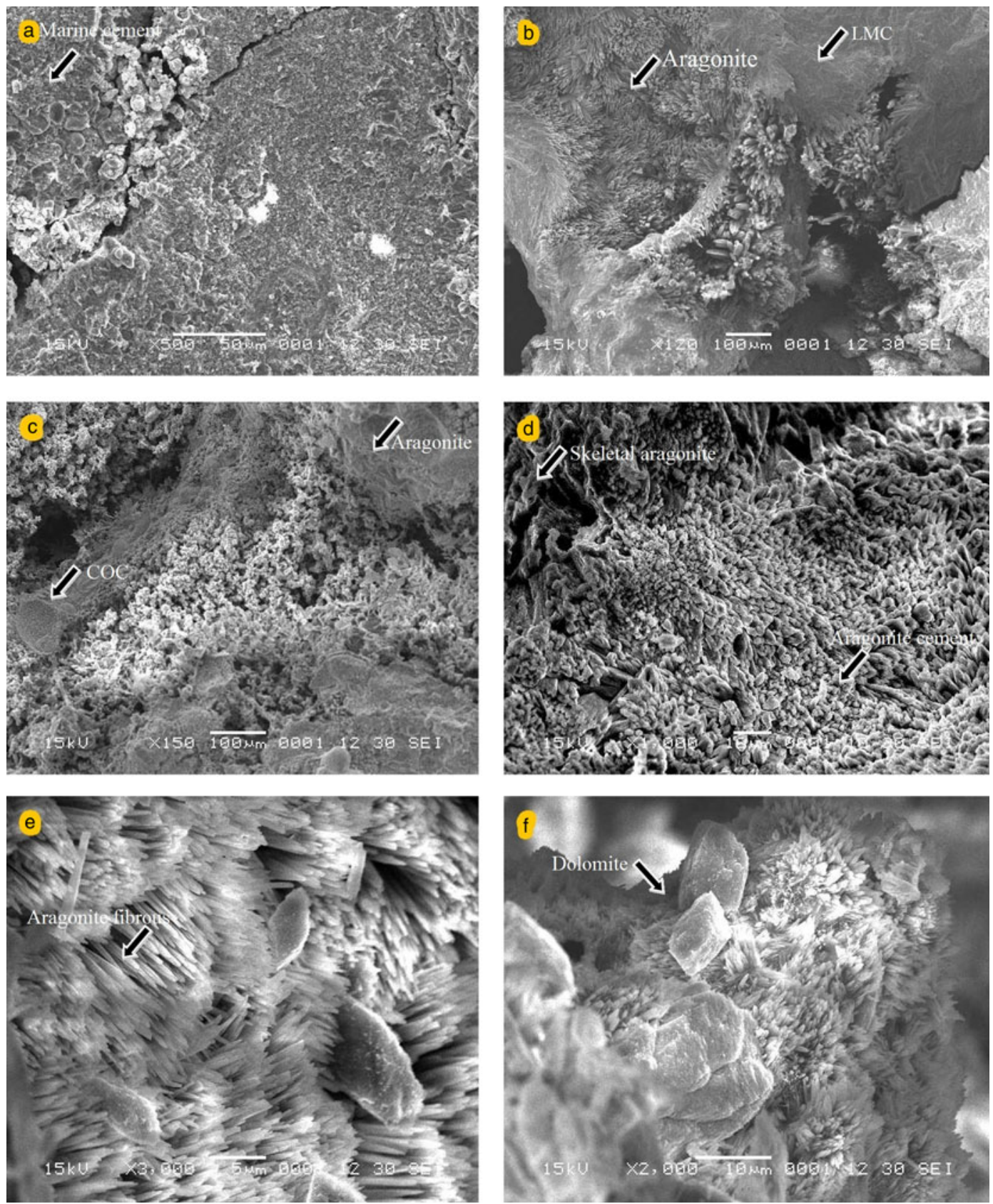

Figure 6. Diagenetic features of the coral reef deposits. (a) The well developed marine cement crust is seen in the reef deposits. (b) Aragonite crystals are overgrown above the pre-existing stable low $\mathrm{Mg}$ calcite cement (LMC). This feature is developed due to the supply of marine water after precipitation of stable carbonate forms (low $\mathrm{Mg}$ calcite). (c) The development of meteoric cements above the aragonite cements (with centre of calcification (COC)) in the terrace is by percolation of meteoric water into reef deposit. (d) The association of skeletal aragonite with aragonite cement along the periphery of the island indicates the marine diagenetic environment. (e, f) The later formed dolomitic crystals overlie above the post-date needle and fibrous shaped aragonite crystals. 
island such as reef framework and reef associated beachrock deposits. The intense cement distribution in the seaward side of the reef framework is probably due to high energy conditions and oceanic water temperature.

The large volume of sea water is moved through the reef framework by waves, tides, $\mathrm{CO}_{2}$ degassing by warming and agitation of marine water. The two types of cements such as aragonite and neomorphic low $\mathrm{Mg}$ calcite was noticed in the coral fragments of the study area (figure $5 \mathrm{f}$ ). The marine cements were observed sporadically in the lower part of the reef framework deposits (figure 6a). They may be due to quick colonized red algae and microbial mats which rendered its surface less permeable. The initial micritic cementation probably further supported for sealing the reef structure surface. The sea water penetrates locally through unsealed gaps and leads to precipitate aragonite crystals on pre-existing skeletal structure (figure $6 \mathrm{~b})$. The well developed wave cut notches and caves suggest the intensive action of waves during sea level low stands. The early stage marine cements are noticed in the periphery of the island reef structure (figure $6 \mathrm{~d}$ ) and other areas covered by meteoric cement, which envelopes probably due to the supply of meteoric water after the precipitation of marine cements (figure 6c). The occurrence of low $\mathrm{Mg}$ calcite in the reef flat is due to the penetration of meteoric water in reef framework deposits during sea level low stands. XRD studies are also supported for the association of marine and meteoric cements.

Dolomite crystals are associated with post-date aragonite and $\mathrm{Mg}$ calcite cements. It occurs as small and subhedral rhombic crystals which grow over the earlier cements (figure 6e and f). Mixed meteoric and marine waters are often unsaturated, while unsaturated with respect to calcite may remain saturated with respect to dolomite. This relationship results in extensive calcite dissolution and the possibility of dolomitization (Moore 2001). Dissolution features are seen in all facies of the study area and this dissolution process is evidenced by secondarily formed low $\mathrm{Mg}$ calcite cements. However, the intensity of dissolution is low in reef framework deposits.

\section{Meteoric diagenesis}

The meteoric diagenesis is possibly modified and reconstructs the original depositional porosity during the movement of diagenetic fluids. The initial effects of this diagenesis may be dissolution, cementation or internal cementation. The presence of cavernous porosity and abundant pore fill-circumgranular calcite cements suggest the phreatic environment (figure 7a). The water moves from the vadose zone to phreatic zone by seepage through a network of small fractures, solution channels, joints, large fractures and pores. The fracture dissolution enlargement enhances vertical fluid conductivity. This system reflected in the unequal morphology of the cements (meniscus) precipitated in the environment (figure $7 \mathrm{~b}$ ). Dissolution of aragonitic skeletons and precipitation of blocky low $\mathrm{Mg}$ calcite cements is most effective during the time of meteoric diagenesis especially in rainy periods (Longman 1980). In few cases mixing of freshwater with seawater may further enhance the aragonite dissolution and calcite precipitation (Budd 1988). Well developed dissolution features and low $\mathrm{Mg}$ calcite cements are noticed in the beach and aeolian facies capped reef cycles of the islands. The study area experienced freshwater diagenesis and void filling calcitic cements in the skeletal structures of phreatic zone is probably due to the semi-arid climatic condition and freshwater lenses within the reef body (figure 7c). However, the limited dissolution evidences, good preservation of aragonite and high $\mathrm{Mg}$ calcite in the top facies of the study area are due to the nonavailability of permanent freshwater lens or freshwater lens moves too rapidly through the sediment (figure $7 \mathrm{~d}$ and e).

The fractured polycrystalline aragonite fiber bundle in the skeletal structure indicates the vadose zone diagenesis. Aragonitic skeletons seem to be much more susceptible to dissolution than aragonite cements, which are preserved in many cases and is overgrown by low $\mathrm{Mg}$ calcite precipitated from freshwater. Same observations have been reported in reef rocks of Bermuda and Bahamas (Schroeder 1973; Gaffey et al 1995). The freshwater diagenesis is with completely altered microstructure and sediment infillings. According to Moore (2001) the dissolved metastable phase (aragonite and $\mathrm{Mg}$ calcite) was precipitated in other places with respect to hydrologic gradient. The large kinetic difference between aragonite dissolution and calcite precipitation implies that $\mathrm{CaCO}_{3}$ dissolved from aragonite is generally transported away from the site of solution. If the water flux in the diagenetic system is large and the water is strongly unsaturated with respect to aragonite then the aragonite grains will undergo total dissolution. So cavernous porosity will be formed and all internal structure within the aragonite skeletal grains will be destroyed (figure 7f). The cavernous porosity is the most significant reaction related to the development of porosity and permeability in the dissolution of metastable solid phase (aragonite and $\mathrm{Mg}$ calcite) and the precipitation of the stable solid phase (calcite). 

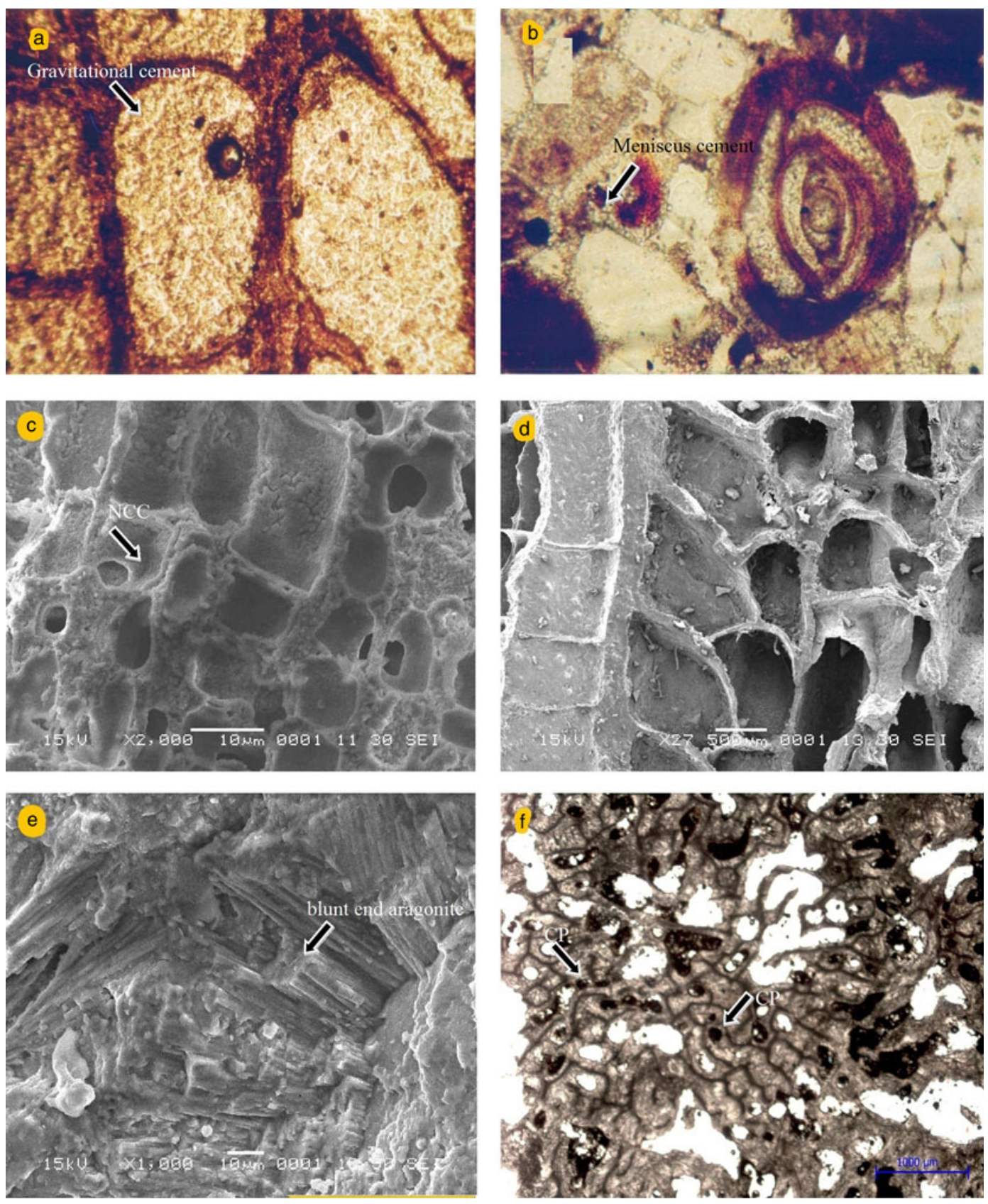

Figure 7. Diagenetic features of the coral reef deposits. (a) Formation of skeletal pore filled calcitic gravitational cement in the coral deposits in the phreatic zone is due to meteoric diagenesis. (b) The meniscus fabrics in the contacts of the mineral grains indicate the meteoric diagenesis in the vadose zone. (c) The void filling neomorphic calcitic cement (NCC) in the reef deposits suggests that the meteoric water diagenesis under semi-arid climatic condition. (d, e) The good preservation of skeletal structure with well developed both blunt end shaped aragonite indicate the limited freshwater diagenesis in topmost layer of the reef deposits. (f) The completely altered micro structures and formation of cavernous porosity (CP) are due to the diagenetic process beneath the reef skeletal framework.

Well preserved coral skeletal rims are partially filled with Fe-calcite in few samples, which indicate the possible environmental condition for the precipitation of iron content. The precipitation of iron is most probably due to less porosity and permeability nature of sediments. This is supported for the burial diagenesis. Under freshwater influence high $\mathrm{Mg}$ calcite cements can be converted to low $\mathrm{Mg}$ calcite in a few thousand years without textural changes, whereas calcitization of aragonite may take a few ten thousands of years (Gavish and Friedman 1969). The low Mg calcites possibly precipitated anytime after the formation of original reef composition. The released $\mathrm{Mg}^{+}$ions during the formation of low mg calcite probably supported for crystallisation of dolomites. 

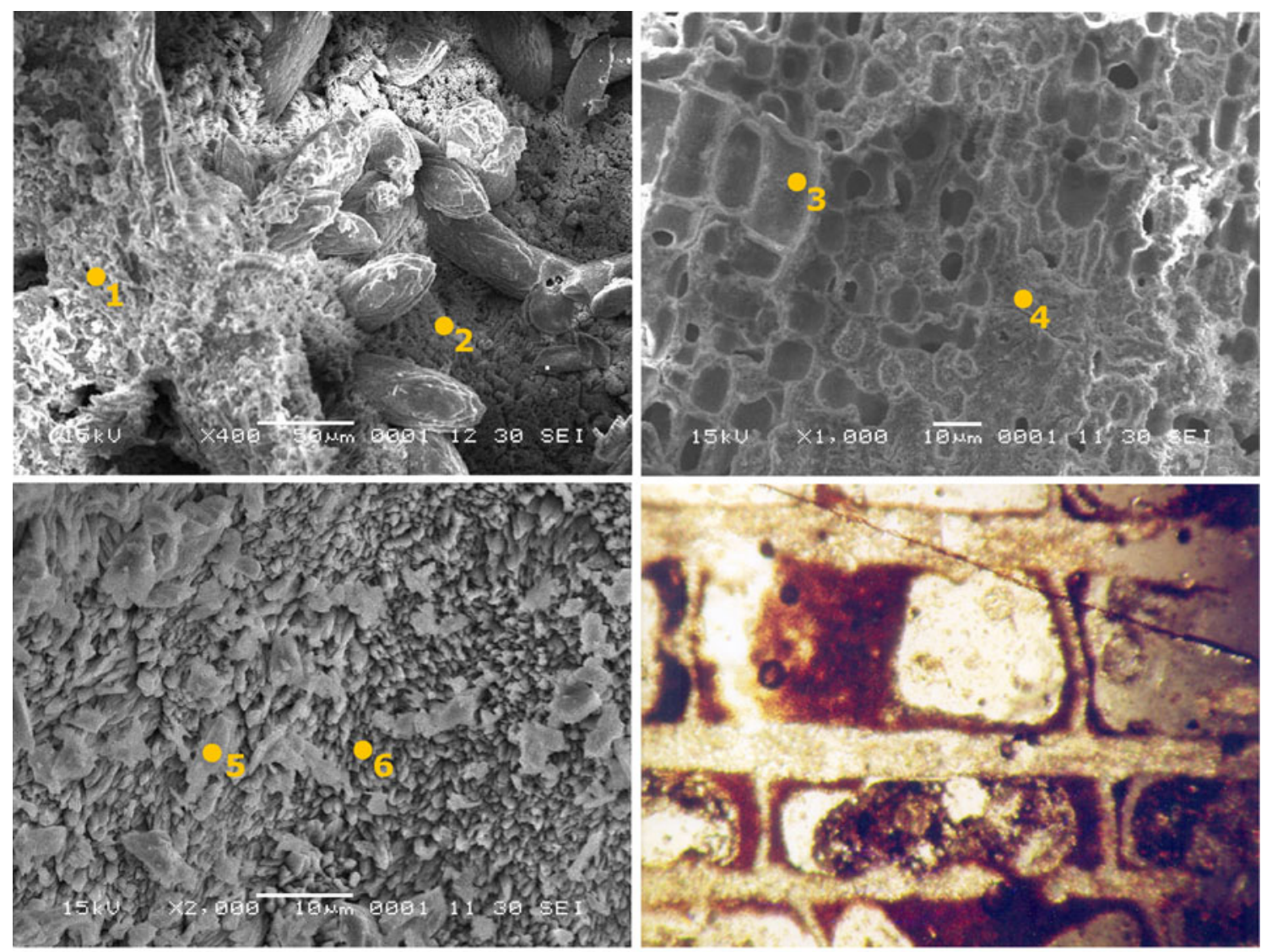

\begin{tabular}{cccccccccc}
\hline S.no & $\mathrm{SIO}_{2}$ & $\mathrm{Al}_{2} \mathrm{O}_{3}$ & $\mathrm{CaO}$ & $\mathrm{MgO}$ & $\mathrm{Fe}_{2} \mathrm{O}_{3}$ & $\mathrm{Na}_{2} \mathrm{O}$ & $\mathrm{K}_{2} \mathrm{O}$ & $\mathrm{P}_{2} \mathrm{O}_{5}$ & $\mathrm{SrCO}_{3}$ \\
\hline 1 & 5.75 & 2.97 & 40.18 & 0.99 & 0.58 & 0.98 & 0.87 & 0.13 & 0.12 \\
2 & 0.61 & 0.69 & 67.06 & 0.2 & 1.54 & 0.49 & 2.35 & 0 & 0 \\
3 & 0 & 0 & 53.96 & 0.06 & 0 & 0.45 & 0.55 & 0 & 0 \\
4 & 0.65 & 0.33 & 56.06 & 3.59 & 0.02 & 0.11 & 1.38 & 0 & 0.14 \\
5 & 0 & 0 & 67.98 & 0.49 & 0.09 & 0.39 & 1.07 & 0.16 & 0 \\
6 & 0 & 0.15 & 57.4 & 1.8 & 0.06 & 0 & 1.37 & 0.06 & 0 \\
\hline
\end{tabular}

Figure 8. EDS analysis of coral samples showing mineral transformation. EDS results showing the traces of Sr and presence of silica and alumina in the reef framework suggest the replacement of primary aragonite by low $\mathrm{Mg}$ calcite and deposition of terrigeneous components respectively. (a) Well developed dog-tooth cementation in the coral reef skeleton, (b) Neomorphic calcite (NC) filled the thick wall of coral skeletal structure, (c) Meteoric diagenesis developed the neomorphic calcite (NC) above the well precipitated marine aragonite cements (MAC). (d) The occurrence of internal sediments within the coral skeletal structures (IS).

According to Schroeder (1973), the elevated strontium concentration in the aragonite cements may be due to stabilized effect. The EDS results suggest that the traces of Sr content probably due to complete replacement of primary aragonite by low $\mathrm{Mg}$ calcite. The presence of $\mathrm{SiO}_{2}$ and $\mathrm{Al}_{2} \mathrm{O}_{3}$ in the reef framework suggesting that they were derived from early stage deposition of terrigeneous components. The association of dog-tooth cementation in the coral skeleton indicates the shallow burial diagenesis (figure 8a) and the development of neomorphic calcite above marine cements suggest the late meteoric diagenesis (figure $8 \mathrm{~b}$ and $\mathrm{c}$ ). Wide varieties of internal sediment occur in the cavities within the reef framework deposits. Much of the internal sedimentation in primary cavities was derived by downward percolation from the depositional interface (figure 8d).

\section{Conclusion}

The Holocene reef and associated beachrock of Gulf of Mannar demonstrate the complex diagenetic features. The earlier stages of diagenesis (marine) are expressed by thickening of primary skeletal aragonite fibers, cement infilling of intraskeletal pores by inorganic aragonite cements and subsequent decrease in initial porosity. The later stage of diagenesis is characterized by partial dissolution of skeletal fibres, subsequent increase of initial porosity and precipitation of secondary inorganic aragonite cements. The freshwater dissolution, association of marine and meteoric cements suggest that the semi-arid climatic condition with marine diagenesis during sea level lowstands and recharge of freshwater lenses during periodic rainfalls. The reef associated beachrocks were deposited in low 
energy environment with some amount of terrigenous matters derived from Precambrian basement rocks and transported into reef area by ephemeral streams and long shore sediment transport process. The associations of anhedral to subhedral nature of lithoclastic matters suggest that the sediments are transported to short distance from confluence point of the river. Vadose zone diagenetic features are limited to intertidal regions suggest that they are probably due to sea level lowstands, semi-arid climatic condition and no pervasive freshwater percolations occurred. Dolomite crystals are probably formed during reflooding of reef terraces by subsequent sea level raise. The duration of specific diagenetic process of this region is mostly unknown because the presence of freshwater lenses probably related to the seasonal rain periods during semi-arid climate.

Moreover, the relative sea level changes may have led to a rapid changing of marine and nonmarine conditions. The dolomite crystals also supported rapid environmental change from marine to hypersaline and from marine to freshwater conditions. The study reveals that reef and associated beachrock can monitor sea level variation and climatic changes not only through their facies and biological components but also through their diagenetic evidences. However, the interpretation of the exact diagenetic pathways frequently slows down by their original, compositional and textural variability of the reef and associated beachrock.

\section{Acknowledgements}

The authors are thankful to the Department of Science and Technology, Earth System Sciences, New Delhi for providing financial support (grant no. SR/S4/ES-44/2003, dated: 01/11/2004). They also thank the authorities of Manonmaniam Sundaranar University, Tirunelveli and KK personally thanks Dr S P Mohan, Professor and Head, Dr Suresh Gandhi, Assistant Professor, Department of Geology, University of Madras, Chennai for providing SEM facilities to carry out this work.

\section{References}

Andre Strasser and Strohmenger C 1997 Early diagenesis in Pleistocene coral reefs, Southern Sinai, Egypt: Response to tectonics, sea level and climatic changes; Sedimentology 44 537-558.

Banerjee P K 2000 Holocene and Late Pleistocene relative sea level fluctuation along the east coast of India; Marine Geol. 167 243-260.
Bathurst R G C 1975 Carbonate sediments and their diagenesis; In: Developments in Sedimentology (Amsterdam: Elsevier), 2nd edn, No.12.

Budd D A 1988 Aragonite to calcite transformation during fresh water diagenesis of carbonates: Insights from pore water chemistry; Bull. Geol. Soc. Am. 100 1260-1270.

Dunham R J 1962 Classification of carbonate rocks according to depositional texture; Am. Assoc. Petrol. Geol. Mem. 1 108-121.

Gaffey S J, Zabielski V P and Bronnimann C 1995 Roles of organics and water in preneomorphic and early neomorphic alteration of coralline aragonites from San Salvador Island, Bahamas; In: Terrestrial and Shallow Marine Geology of the Bahamas and Bermuda (eds) Curran H A and White B, Geol. Soc. Am Spec. Paper 300 233250.

Gavish E and Friedman G M 1969 Progressive diagenesis in Quaternary to Late Tertiary carbonate sediments: Sequence and time scale; J. Sedim. Petrol. 39 9801006.

Gischler E and Lomando A J 1997 Holocene cemented beach deposits in Belize; Sedim. Geol. 110 277-297.

Helen McGregor V and Michael Gagan K 2003 Diagenesis and geochemistry of Porites corals from Papua New Guinea: Implications for paleoclimate reconstruction; Geochim Cosmochim Acta 67(12) 2147-2156.

Hussein Sayani R, Cobb K M, Cohen A L, Crawford Elliott W, Nurhati I S, Dunbar R B, Rose K A and Zaunbrecher L K 2011 Effects of diagenesis on paleoclimate reconstructions from modern and young fossil corals; Geochim Cosmochim Acta $\mathbf{7 5}$ 6361-6373.

Krishna Kumar S, Chandrasekar N, Seralathan P and Godson P S 2011 Depositional environment and faunal assemblages of the reef and associated beachrock at Rameswaram and Keelakkarai group of Islands, Gulf of Mannar, India; Frontiers of Earth Sciences in China 5(1) 65-69.

Land L S and Moore C H 1980 Lithification, micritization and syndepositional diagenesis of biolithites on the Jamaican Island slope; J. Sedim. Petrol. 50 357-370.

Longman M W 1980 Carbonate diagenetic textures from near surface diagenetic environment; Am. Asso. Pet. Geol. Bull. 26 461-487.

Moore C H 2001 Carbonate reservoirs: Porosity evolution and diagenesis in a sequence stratigraphic framework, Elsevier, Netherlands.

Muller A, Gagan M K and McCulloch M T 2001 Early marine diagenesis in corals and geochemical consequences for paleoceanographic reconstructions; Geophys. Res. Lett. 28 4471-4474.

Nicola Allison, Adrian Finch A, Jody Webster M and David Clague A 2007 Palaeo-environmental records from fossil corals: The effects of submarine diagenesis on temperature and climate estimates; Geochim Cosmochim Acta 71 4693-4703.

Perrin C 2003 Compositional heterogeneity and microstructural diversity of coral skeletons: Implications for taxonomy and control on early diagenesis; Coral Reefs $\mathbf{2 2}$ 109-120.

Purnachandra Rao V, Kessarkar P M, Krumbein W E, Krajewski K P and Robert Schneiders J 2003 Microbial dolomite crusts from the carbonate platform off western India; Sedimentology $\mathbf{5 0}$ 819-830.

Rajamanickam G V and Loveson V J 1990 Results of radio carbon dating from some beach terraces around Rameswaram Island; In: Sea level variation and its impact on coastal environment (ed.) Rajamanickam G V, Tamil University Publications, Thanjavur, pp. 389-402. 
Ramkumar M U 2008 Carbonate diagenesis in the Kallankurichchi formation, Ariyalur group, South India and its implications on petroleum prospects; J. Geol. Soc. India 71 407-418.

Ramkumar M, Pattabhi Ramayya M and Gandhi M S 2000 Beachrock exposures at wave cut terraces of modern Godavari delta: Their genesis, diagenesis and indications on coastal submergence and sea level rise; Indian J. Marine Sci. 29 219-223.
Schroeder J H 1973 Submarine and vadose cements in Pleistocene Bermuda reef rock; Sedim. Geol. 10 179-204.

Stoddart D R and Gopinathapillai C S 1972 Raised reef of Ramanathapuram, South India; Trans. Inst. British. Geog. 56 111-125.

Woodroffe C D and Gagan M K 2000 Coral microatolls from the central Pacific record late Holoce El Nino; Geophys. Res. Lett. 27(10) 1511-1514.

MS received 4 March 2011; revised 30 January 2012; accepted 3 February 2012 